\title{
Mosla dianthera Decreases Immediate-Type Allergic Reaction and Tumor Necrosis Factor- $\alpha$ Production
}

\author{
Sang-Hyun Kim, ${ }^{a, \#}$ Hoon Jeon, ${ }^{b, \#}$ Soyoung Lee, ${ }^{a}$ Hee-Young Son, ${ }^{a}$ Seung-Bin Park, ${ }^{a}$ \\ Mi-Sun Kim, ${ }^{a}$ Eun-Ju Choi, ${ }^{a}$ Jong-Pil Lim, ${ }^{b}$ Jae-Soon Eun, ${ }^{b}$ Jeong-Suk Park, ${ }^{c}$ \\ and Tae-Yong Shin ${ }^{b, *}$
}

${ }^{a}$ Cell \& Matrix Research Institute, Department of Pharmacology, School of Medicine, Kyungpook National University, 101 Dongindong 2 Ga, Jung-gu, Daegu 700-422, Republic of Korea, ${ }^{b}$ College of Pharmacy, Woosuk University, 490 Hujeong-ri, Samrye-eup, Wanju-gun, Jeonbuk 565-701, Republic of Korea and ${ }^{c}$ Department of Oriental Alternative Medicine, Nambu University, 864-1 Wolgyedong, Gwangsan-gu, Gwangju 506-706, Republic of Korea

(Received January 7, 2008; Accepted May 20, 2008)

\begin{abstract}
Immediate-type hypersensitivity is involved in many allergic diseases such as asthma, allergic rhinitis, and sinusitis. The discovery of drugs for the treatment of allergic disease is an important subject in human health. Stimulation of mast cells releases inflammatory mediators, such as histamine, and proinflammatory cytokines with immune regulatory properties. We investigated the effect of the aqueous extract of Mosla dianthera (M. dianthera) (Maxim) (AEMD) on the immediate-type allergic reaction and studied its possible mechanisms of action using the model of mast cell-mediated allergic reaction. AEMD dose dependently inhibited compound 48/80-induced systemic allergic reaction and serum histamine release in mice. AEMD attenuated immunoglobulin E (IgE)-mediated skin allergic reaction and histamine release from mast cells. In addition, AEMD decreased the gene expression and production of tumor necrosis factor (TNF)- $\alpha$ in phorbol 12-myristate 13-acetate (PMA) and calcium ionophore A23187-stimulated human mast cells. Our findings provide evidence that AEMD inhibits the mast cell-derived allergic reaction and that TNF- $\alpha$ is involved in these effects. These findings indicate that AEMD could be a candidate as an antiallergic agent.
\end{abstract}

Key words — Mosla dianthera, allergic reaction, mast cell, histamine, tumor necrosis factor- $\alpha$

\section{INTRODUCTION}

Mast cells, which are constituents of virtually all organs and tissues, are important mediators of allergic responses such as allergic inflammation and hypersensitivity. The immediate-type allergic reaction (hypersensitivity) is an acute systemic allergic reaction mediated by histamine released in response to the antigen cross-linking of immunoglobulin E (IgE) bound to FceRI on mast cells. After activation via FceRI, mast cells start the process of degranulation which results in the release of mediators, such as products of arachidonic acid metabolism and an array of inflammatory cytokines. ${ }^{1-3)}$ Among the inflammatory substances released from mast cells,

\footnotetext{
*To whom correspondence should be addressed: College of Pharmacy, Woosuk University, 490 Hujeong-ri, Samryeeup, Wanju-gun, Jeonbuk 565-701, Republic of Korea. Tel.: +82-63-290-1572; Fax: +82-63-290-1567; E-mail: tyshin@woosuk.ac.kr

\#These authors contributed equally to this work.
}

histamine remains the best-characterized and most potent vasoactive mediator implicated in the acute phase of immediate hypersensitivity. ${ }^{4,5)}$

Anti-dinitrophenyl (DNP) IgE antibody and antigen have been established to induce passive cutaneous anaphylaxis (PCA) reactions as a typical in vivo model of hypersensitivity. Mast cell degranulation can also be elicited by nonimmunologic stimulators such as neuropeptides, basic compounds, complement components, and certain drugs. ${ }^{6)} \mathrm{Com}-$ pound $48 / 80$ and polymers of basic amino acids, such as substance $\mathrm{P}$, are some of the most potent stimulators of mast cells. Thus an appropriate amount of compound 48/80 has been used as a direct and convenient reagent to study the mechanism of anaphylactic allergic reaction.

The signaling pathway leading to degranulation of mast cells after engagement of the Fc $\varepsilon$ RI receptor has been extensively characterized. ${ }^{4)}$ Activation of mast cells leads to phosphorylation of tyrosine kinase, mobilization of internal calcium, and release 
of inflammatory cytokines. Although mast cells also store small amounts of cytokines in their granules, these cells dramatically increase the production of tumor necrosis factor (TNF)- $\alpha$ and other cytokines after their surface FceRI is cross-linked with specific antigen. ${ }^{7,8)}$

Anal therapy is a drug delivery system through the anus and is utilized in patients who have difficulty with oral administration. Absorbing a drug in the rectum avoids the first-pass effect in the liver and allows it to circulate directly in the whole body. $\left.{ }^{9}, 10\right)$ Thus anal therapy is expected to have a better effect than oral therapy due to the increased absorption rate and potent medical action.

Mosla dianthera (M. dianthera) Maxim has been used for centuries as traditional Oriental medicine. This crude drug contains volatile flavor compounds and aroma-active compounds, mainly carvone, limonene, and beta-caryophyllene, and linalool, 3-hexenol, and myrcene, respectively. ${ }^{11)}$ It is native to Korea, China, Japan, and Vietnam and an annual aromatic plant of the labiatae family. It has been used as a medicinal plant to treat colds, headaches, and intestinal and skin diseases. ${ }^{12,13)}$ In this study, we investigated the antiallergic effects of the aqueous extract of $M$. dianthera (AEMD) and attempted to understand the mechanism of its effect.

\section{MATERIALS AND METHODS}

Animals — The original stock of male Imprinting Control Region (ICR) mice and male SpragueDawley rats were purchased from the Dae-Han Experimental Animal Center (Daejeon, Korea). The animals were maintained in the College of Pharmacy, Woosuk University. The animals were housed 5-10 per cage in a laminar air flow room (conventional conditions), maintained at a temperature of $22 \pm 2^{\circ} \mathrm{C}$, with a relative humidity of $55 \pm 5 \%$ throughout the study. The care and treatment of the mice were in accordance with the guidelines established by the Public Health Service Policy on the Humane Care and Use of Laboratory Animals and were approved by the Institutional Animal Care and Use Committee.

Reagents and Cell Culture-Compound 48/80, anti-DNP IgE, DNP-human serum albumin (HSA), $\alpha$-minimal essential medium ( $\alpha$-MEM), $o$ phthaldialdehyde, phorbol 12-myristate 13-acetate (PMA), and calcium ionophore A23187 were purchased from Sigma Chemical Co. (St Louis,
MO, U.S.A.). The human mast cell line (HMC-1) was grown in Iscove's media (Life Technologies, Grand Island, NY, U.S.A.) supplemented with $10 \%$ Fetal bovine serum (FBS) and glutamine $2 \mathrm{mM}$ at $37^{\circ} \mathrm{C}$ in $5 \% \mathrm{CO}_{2}$.

Preparation of AEMD — The plant of $M . d i$ anthera was collected in Soonchnag, South Korea, on the August 13, 2000. A voucher specimen (WSP-00-42) was deposited in the Herbarium of the College of Pharmacy, Woosuk University. $M$. dianthera was ground $(1000 \mathrm{rpm}$, $30 \mathrm{sec})$ at room temperature using a Micro Hammer Cutter Mill (Culatti Co., Zurich, Switzerland). The particle size was $0.5-2 \mathrm{~mm}$ after grinding. The plant sample $(60 \mathrm{~g})$ was extracted twice with purified water $(500 \mathrm{ml})$ at $70^{\circ} \mathrm{C}$ for $5 \mathrm{hr}$ in a water bath. The extract was filtered through Whatman No. 1 filter paper and the filtrate was lyophilized using a $0.45 \mu \mathrm{m}$ syringe filter. The yield of dried extract from starting crude materials was about $7.5 \%$. The dried extract was dissolved in saline or Tyrode buffer A (4-(2-hydroxyethyl)1-piperazineethanesulfonic acid (HEPES) $10 \mathrm{mM}$, $\mathrm{NaCl} 130 \mathrm{mM}, \mathrm{KCl} 5 \mathrm{mM}, \mathrm{CaCl}_{2} 1.4 \mathrm{mM}, \mathrm{MgCl}_{2}$ $1 \mathrm{mM}$, glucose $5.6 \mathrm{mM}, 0.1 \%$ bovine serum albu$\min$ ) before use.

Compound 48/80-induced Systemic Reaction-Mice were given an intraperitoneal injection of $8 \mathrm{mg} / \mathrm{kg}$ body weight (BW) of the mast cell degranulator compound 48/80. AEMD was dissolved in saline and anally administered $1 \mathrm{hr}$ before the injection of compound 48/80 ( $n=10 /$ group). Mortality was monitored for $1 \mathrm{hr}$ after induction of anaphylactic shock. After the mortality test, blood was obtained from the heart of each mouse to measure the serum histamine content.

PCA Reaction — An IgE-dependent cutaneous reaction was examined as previously described. ${ }^{14)}$ The PCA reaction was generated by sensitizing skin with an intradermal injection of anti-DNP IgE followed $48 \mathrm{hr}$ later with an injection of DNP-HSA into the mouse tail vein. The mice were injected intradermally with $0.5 \mu \mathrm{g}$ of anti-DNP IgE. After $48 \mathrm{hr}$, each mouse was received an injection of $1 \mu \mathrm{g}$ of DNP-HSA containing 4\% Evans blue $(1: 4)$ via the tail vein. Thirty minutes after the challenge, the mice were killed and the dorsal skin was removed for measurement of the pigmented area. The amount of dye was determined colorimetrically after extraction with $1 \mathrm{ml}$ of Potassium hydroxide $(\mathrm{KOH}) 1 \mathrm{M}$ and $9 \mathrm{ml}$ of a mixture of acetone and phosphoric acid $(5: 13) .{ }^{14)}$ The intensity of ab- 
sorbance was measured at $620 \mathrm{~nm}$ in a spectrophotometer (UV-1201, Shimadzu, Kyoto, Japan).

Preparation of Serum and Histamine Determination — The blood was centrifuged at $400 \mathrm{~g}$ for $10 \mathrm{~min}$. The serum was withdrawn and the histamine content was measured using the $o$ phthaldialdehyde spectrofluorometric procedure. ${ }^{15)}$ The fluorescence intensity was measured at the emission wavelength of $438 \mathrm{~nm}$ and excitation wavelength of $353 \mathrm{~nm}$ using a spectrofluorometer (RF-5301 PC, Shimadzu).

Preparation of Rat Peritoneal Mast Cells (RPMC) — RPMC were isolated as previously described. ${ }^{10)}$ In brief, rats were anesthetized by ether and injected with $20 \mathrm{ml}$ of Tyrode buffer B ( $\mathrm{NaCl} 137 \mathrm{mM}$, glucose $5.6 \mathrm{mM}, \mathrm{NaHCO}_{3} 12 \mathrm{mM}$, $\mathrm{KCl} 2.7 \mathrm{mM}, \mathrm{NaH}_{2} \mathrm{PO}_{4} 0.3 \mathrm{mM}$, and $0.1 \%$ gelatin) into the peritoneal cavity, and the abdomen was gently massaged for about $90 \mathrm{sec}$. The peritoneal cavity was carefully opened, and the fluid containing peritoneal cells was aspirated with a Pasteur pipette. The peritoneal cells were sedimented at $150 \mathrm{~g}$ for $10 \mathrm{~min}$ at room temperature and resuspended in Tyrode buffer B. Mast cells were separated from the major components of rat peritoneal cells, i.e., macrophages and small lymphocytes. In brief, peritoneal cells were suspended in $1 \mathrm{ml}$ of Tyrode buffer $\mathrm{B}$, layered on $2 \mathrm{ml}$ of metrizamide $(22.5 \mathrm{w} / \mathrm{v} \%)$, and centrifuged at room temperature for $15 \mathrm{~min}$ at $400 \mathrm{~g}$. The cells remaining at the buffer-metrizamide interface were aspirated and discarded; the cells in the pellet were washed and resuspended in $1 \mathrm{ml}$ of Tyrode buffer A. Mast cell preparations were about 95\% pure as assessed by toluidine blue staining. More than $97 \%$ of the cells were viable as judged by the trypan blue dye-exclusion test.

Inhibition of Histamine Release — RPMC suspensions $\left(2 \times 10^{5}\right.$ cells $\left./ \mathrm{ml}\right)$ were sensitized with anti-DNP IgE $(10 \mu \mathrm{g} / \mathrm{ml})$ for $16 \mathrm{hr}$. The cells were preincubated with AEMD $(0.01$ to $1 \mathrm{mg} / \mathrm{ml})$ at $37^{\circ} \mathrm{C}$ for $10 \mathrm{~min}$ prior to the challenge with DNP-HSA $(1 \mu \mathrm{g} / \mathrm{ml})$ for $10 \mathrm{~min}$. The cells were separated from the released histamine by centrifugation at $400 \mathrm{~g}$ for 5 min at $4^{\circ} \mathrm{C}$.

Reverse-transcriptase Polymerase Chain Reaction (RT-PCR) — The total cellular RNA was isolated from the cells $\left(1 \times 10^{6} /\right.$ well in a 24 -well plate) after stimulation with PMA $(20 \mathrm{nM})$ and A23187 $(1 \mu \mathrm{M})$ with or without AEMD for $2 \mathrm{hr}$ using a TRI reagent (Molecular Research Center, Cincinnati, OH, U.S.A.) according to the manufacturer's protocol. The first-strand complemen- tary DNA (cDNA) was synthesized using the Superscript II reverse transcriptase (Life Technologies). RT-PCR was used to analyze the expression of mRNA for TNF- $\alpha$ and $\beta$-actin (internal control). The conditions for the reverse transcription and PCR steps were similar to those previously described. ${ }^{16)}$ The primer sets were chosen with the Primer 3 program (Whithead Institute, Cambridge, MA, U.S.A.). The cycle number was optimized to ensure product accumulation in the exponential range. The amplified products were separated by electrophoresis on $2 \%$ agarose gel containing ethidium bromide, documented using a Kodak DC 290 digital camera, and digitized with UN-SCAN-IT software (Silk Scientific, Orem, UT, U.S.A.). The band intensity was normalized to that of $\beta$-actin in the same sample.

Western Blot Analysis — Cell extracts were prepared using the detergent lysis procedure. Samples of protein $(50 \mu \mathrm{g})$ were electrophoresed using 12\% sodium dodecyl sulfate (SDS)-polyacrylamide gel electrophoresis (PAGE), as described elsewhere, ${ }^{17)}$ and then transferred to a nitrocellulose membrane. The amount of TNF- $\alpha$ was determined using antiTNF- $\alpha$ antibody (R\&D Systems Inc., Minneapolis, MN, U.S.A.). Immunodetection was performed using an enhanced chemiluminescence detection kit (Amersham, Piscataway, NJ, U.S.A.).

Statistical Analysis — Statistical analyses were performed using SAS statistical software (SAS Institute, Cary, NC, U.S.A.). Treatment effects were analyzed using one-way analysis of variance, followed by Duncan's multiple-range test. A value of $p<0.05$ was used to indicate statistically significant differences.

\section{RESULTS}

\section{AEMD Inhibits Compound 48/80-induced Sys- temic Allergic Reaction}

To determine the effect of AEMD on allergic reaction, an in vivo model of systemic reaction was used. Compound 48/80 (8 mg/kg BW) was used as a model for the induction of a systemic fatal allergic reaction. After the intraperitoneal injection of compound 48/80, the mice were monitored for $1 \mathrm{hr}$, after which the mortality rate was determined. As shown in Table 1, injection of compound 48/80 in mice induced fatal shock in $100 \%$ of animals. When AEMD was anally administered at concentrations ranging from 0.01 to $1 \mathrm{mg} / \mathrm{g} \mathrm{BW}$ for $1 \mathrm{hr}$, the mor- 
Table 1. Effects of AEMD on Compound 48/80-Induced Systemic Anaphylaxis

\begin{tabular}{ccc}
\hline \hline $\begin{array}{c}\text { AEMD treatment } \\
(\mathrm{mg} / \mathrm{g} \mathrm{BW})\end{array}$ & $\begin{array}{c}\text { Compound 48/80 } \\
(8 \mathrm{mg} / \mathrm{kg} \mathrm{BW})\end{array}$ & Mortality (\%) \\
\hline None (saline) & + & 100 \\
0.01 & + & 100 \\
0.05 & + & 80 \\
0.1 & + & 40 \\
0.5 & + & 0 \\
1 & - & 0 \\
\hline
\end{tabular}

Groups of mice ( $n=10$ /group) were anally pretreated with $200 \mu \mathrm{l}$ of saline or AEMD at various doses $1 \mathrm{hr}$ before the intraperitoneal injection of compound 48/80. Mortality (\%) within $1 \mathrm{hr}$ following compound $48 / 80$ injection is represented as the number of dead mice $\times 100 /$ total number of experimental mice. BW, body weight.

Table 2. Time-Dependent Effects of AEMD on Compound 48/80-Induced Systemic Anaphylaxis

\begin{tabular}{cccc}
\hline \hline $\begin{array}{c}\text { AEMD treatment } \\
(\mathrm{mg} / \mathrm{g} \mathrm{BW})\end{array}$ & $\begin{array}{c}\text { Compound 48/80 } \\
(8 \mathrm{mg} / \mathrm{kg} \mathrm{BW})\end{array}$ & $\begin{array}{c}\text { Time } \\
(\mathrm{min})\end{array}$ & Mortality (\%) \\
\hline None (saline) & + & & 100 \\
1 & + & 0 & 0 \\
& + & 5 & 0 \\
& + & 10 & 80 \\
& + & 20 & 100 \\
\hline
\end{tabular}

Mice ( $n=10 /$ group) were anally pretreated with $200 \mu$ of saline or AEMD. AEMD $(1 \mathrm{mg} / \mathrm{g})$ was given 5,10 , and $20 \mathrm{~min}$ after the intraperitoneal injection of compound 48/80. Mortality (\%) within $1 \mathrm{hr}$ following compound $48 / 80$ injection is represented as the number of dead mice $\times 100 /$ total number of experimental mice. BW, body weight.

tality with compound 48/80 was dose dependently reduced. In addition, the mortality of mice administered AEMD anally ( $1 \mathrm{mg} / \mathrm{g}) 5,10$, and $20 \mathrm{~min}$ after compound $48 / 80$ injection increased time dependently (Table 2).

\section{AEMD Decreases Compound 48/80-induced Serum Histamine Release}

The effect of AEMD on compound 48/80induced serum histamine release was investigated. AEMD was given at concentrations ranging from 0.01 to $1 \mathrm{mg} / \mathrm{g} \mathrm{BW} 1 \mathrm{hr}$ before ( $n=10$ /group) compound 48/80 injection (Fig. 1). The inhibition rate due to treatment with AEMD was significant at doses of 0.1 and $1 \mathrm{mg} / \mathrm{g}$.

\section{AEMD Inhibits the PCA Reaction}

PCA is one of the most important in vivo models of local allergic reaction. ${ }^{9)}$ As described in the experimental procedures, local extravasation was induced by a local injection of anti-DNP IgE, followed by an intravenous antigenic challenge.

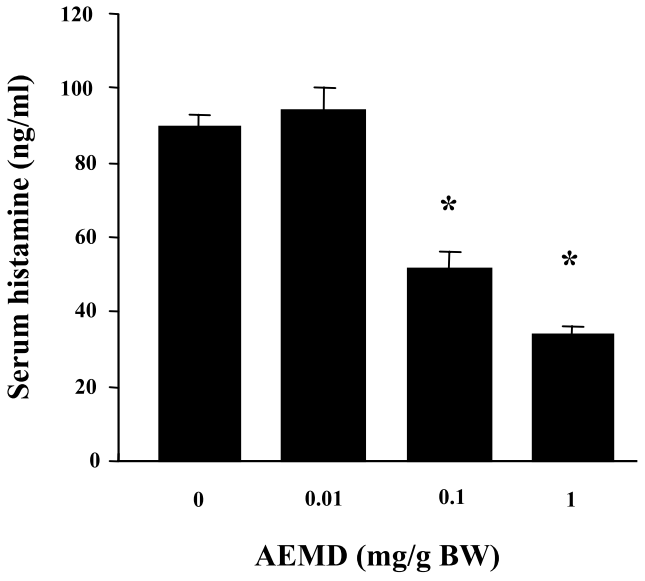

Fig. 1. Effects of AEMD on Compound 48/80-Induced Serum Histamine

Release Groups of mice ( $n=10$ /group) were anally pretreated with $200 \mu \mathrm{l}$ of saline or AEMD. AEMD was given at various doses $1 \mathrm{hr}$ before the injection of compound $48 / 80$. The compound $48 / 80$ solution was given intraperitoneally to the group of mice. The blood was obtained from the heart of each mouse, and histamine content was measured using the $o$-phthaldialdehyde spectrometric procedure. Each bar represents the mean \pm SEM of three independent experiments. ${ }^{*}$ Significant difference at $p<0.05$.

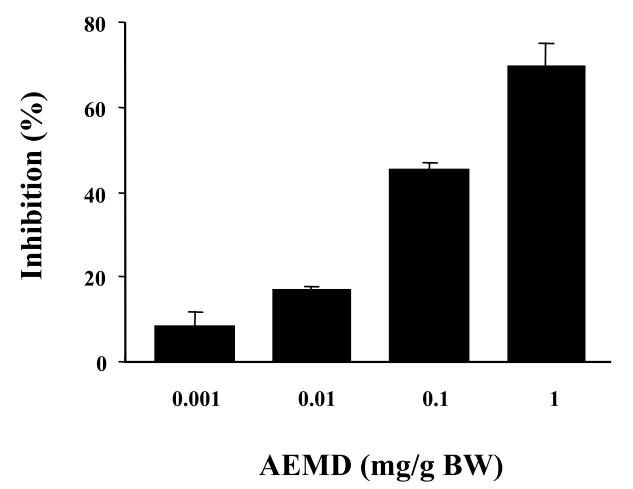

Fig. 2. Effects of AEMD on the IgE-Mediated PCA

Groups of mice ( $n=5 /$ group) were treated with saline or AEMD. AEMD was anally administered $1 \mathrm{hr}$ prior to the challenge with antigen. Data represent the mean \pm SEM of two independent experiments.

AEMD dose dependently inhibited the PCA reaction (Fig. 2).

AEMD Reduces IgE-mediated Histamine Release from RPMCs

The inhibitory effects of AEMD on IgEmediated histamine release from RPMCs are shown in Fig. 3. AEMD dose dependently inhibited antiDNP IgE-mediated histamine release at concentrations of 0.1 and $1 \mathrm{mg} / \mathrm{ml}$.

AEMD Inhibits Gene Expression and Production of TNF- $\alpha$ from HMC-1 Cells

TNF- $\alpha$ is one of the most important proinflam- 


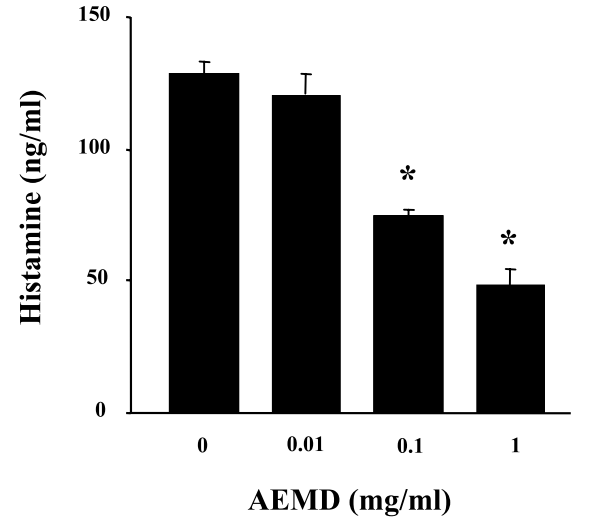

Fig. 3. Effects of AEMD on the IgE-Mediated Histamine Release from RPMCs

Cells were preincubated with AEMD 10 min prior to incubation with DNP-HSA. Each bar represents the mean \pm SEM of three independent experiments. ${ }^{*}$ Significant difference at $p<0.05$.

matory cytokines. Therefore we examined the effects of AEMD on the gene expression and production of TNF- $\alpha$ using RT-PCR and Western blotting, respectively. HMC-1 are useful for studying the synthesis of mediators and cytokine activation pathways. ${ }^{5)}$ As shown in Fig. 4A, the gene expression of TNF- $\alpha$ was increased after stimulation with PMA and A23187. Pretreatment with AEMD inhibited PMA- and A23187-induced production of TNF- $\alpha$ mRNA. Pretreatment with AEMD also decreased PMA- and A23187-induced production of TNF- $\alpha$ protein (Fig. 4B). The concentration of AEMD used in the experiment did not interfere with the viability of cells as assessed in the trypan blue dye-exclusion test.

\section{DISCUSSION}

Mast cell-mediated hypersensitivity is a lifethreatening syndrome induced by the sudden systemic release of inflammatory mediators, such as histamine, heparin, lipid derived mediators, and various cytokines from mast cells. Mast cells are located throughout the human body and upon allergen exposure, they are stimulated via the IgE receptor. ${ }^{2)}$

The results of this study demonstrated that AEMD has the antiallergic properties. Pretreatment with AEMD profoundly inhibited the compound 48/80-induced systemic reaction and IgEmediated local allergic reaction. AEMD inhibited IgE-mediated histamine release from RPMCs. These results indicate that mast cell-mediated hypersensitivity is inhibited by AEMD. It is known
$\mathbf{A}$
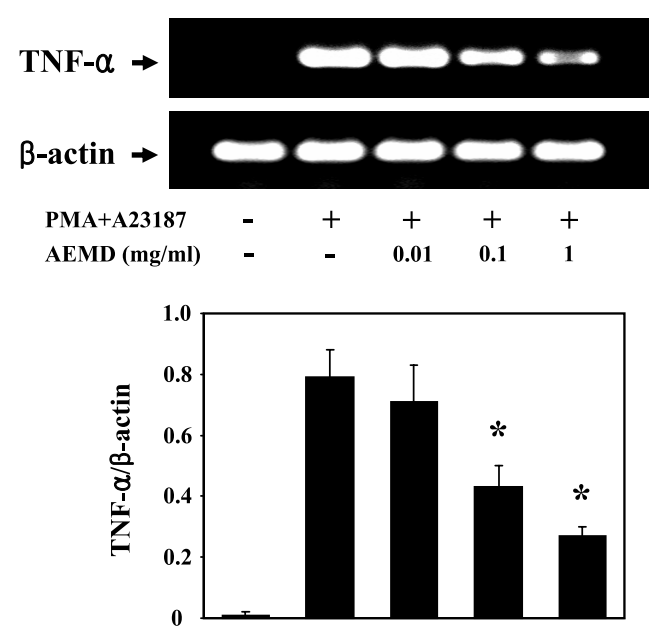

B
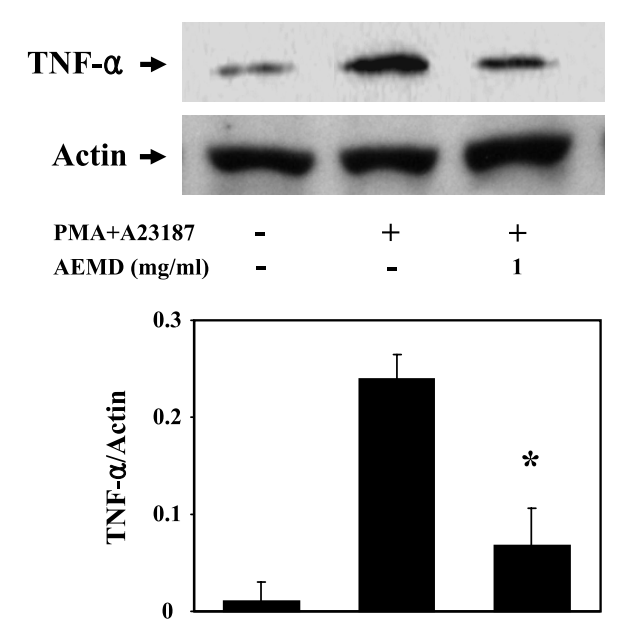

Fig. 4. Inhibitory Effects of AEMD on Gene Expression and Production of TNF- $\alpha$ in HMC-1 Cells

HMC-1 cells were treated with AEMD for 30 min before being stimulated with PMA $(20 \mathrm{nM})$ and A23187 $(1 \mu \mathrm{M})$. Extraction and analysis of mRNA and protein were performed as described in Materials and methods. (A) The gene expression of TNF- $\alpha$ was analyzed using RT-PCR. (B) The production of TNF- $\alpha$ was analyzed using Western blotting. The band intensities of TNF- $\alpha$ mRNA and protein were quantitated by densitometry and normalized against $\beta$-actin and actin, respectively. ${ }^{*}$ Significant difference at $p<0.05$.

that stimulation of mast cells with compound 48/80 or IgE initiates the activation of a signal transduction pathway that leads to histamine release. ${ }^{4,18)}$ Several recent studies have shown that compound 48/80 and other polybasic compounds are able, apparently directly, to activate G-proteins. ${ }^{19)}$ It was reported that compound 48/80 increases the permeability of the lipid bilayer membrane by causing a perturbation of the membrane. ${ }^{20)}$ This result indicates that the increase in membrane permeability may be an essential trigger for the release of the 
mediator from mast cells. In this sense, antiallergic agents with a membrane stabilizing action may be desirable. AEMD may act on the lipid bilayer membrane, thus preventing the perturbation induced by compound $48 / 80$.

The PCA is one of the most important in vivo models of anaphylaxis in local allergic reactions. The mice administered AEMD were protected from IgE-mediated PCA. This finding suggests that AEMD might be useful in the treatment of allergic skin reactions.

Mast cell-derived cytokines, especially TNF- $\alpha$, have critical biological activity in allergic reactions. It has been reported that mast cells are a principal source of TNF- $\alpha$ in the human dermis, and degranulation of mast cells in the dermal endothelium is abrogated by the anti-TNF- $\alpha$ antibody. ${ }^{21)}$ This report may indicate that a decrease in TNF- $\alpha$ is a one of the key indicators of reduced allergic symptoms. The HMC-1 cell line is useful for studying cytokine activation pathways. ${ }^{22)}$ AEMD inhibited the production of TNF- $\alpha$ in PMA- and A23187-stimulated HMC-1 cells. This result may suggest that one possible pathway of the antiallergic effects of AEMD results from the reduction of TNF- $\alpha$ release from mast cells. The effect of AEMD on TNF- $\alpha$ production by mast cells in vivo and the contribution of mast cells as a source of TNF- $\alpha$ during allergic reactions are important areas for future studies. The results obtained in the present study show that AEMD contributes to the prevention or treatment of mast cell-mediated allergic reaction.

Acknowledgements This work was supported by the Korea Research Foundation Grant funded by the Korean Government (MOEHRD) (The Regional Research Universities Program/Center for Healthcare Technology Development), by the KOSEF grant funded by the Korea government (MOST) (No. M10646020001-06N4602-00110), and by the MOEHRD, Basic Research Promotion Fund (KRF2006-003-E00427).

\section{REFERENCES}

1) Marone, G., Triggiani, M., Genovese, A. and Paulis, A. D. (2005) Role of human mast cells and basophils in bronchial asthma. Adv. Immunol., 88, 97-160.

2) Kemp, S. F. and Lockey, R. F. (2002) Anaphylaxis: a review of causes and mechanisms. J. Allergy Clin. Immunol., 110, 341-348.
3) Galli, S. J., Nakae, S. and Tsai, M. (2005) Mast cells in the development of adaptive immune responses. Nat. Immunol., 6, 135-142.

4) Galli, S. J., Kalesnikoff, J., Grimbaldeston, M. A., Piliponsky, A. M., Williams, C. M. and Tsai, M. (2005) Mast cells as "tunable" effector and immunoregulatory cells: recent advances. Annu. Rev. Immunol., 23, 749-786.

5) Kim, S. H., Jun, C. D., Suk, K., Choi, B. J., Lim, H., Park, S., Lee, S. H., Shin, H. Y., Kim, D. K. and Shin, T. Y. (2006) Gallic acid inhibits histamine release and proinflammatory cytokine production in mast cells. Toxicol. Sci., 91, 123-131.

6) Lagunoff, D., Martin, T. W. and Read, G. (1983) Agents that release histamine from mast cells. Annu. Rev. Pharmacol. Toxicol., 23, 331-351.

7) Galli, S. J., Gordon, J. R. and Wershil, B. K. (1991) Cytokine production by mast cells and basophils. Curr. Opin. Immunol., 3, 865-872.

8) Bradding, P., Feather, I. H., Wilson, S., Bardin, P. G., Heusser, C. H., Holgate, S. T. and Howarth, P. H. (1993) Immunolocalization of cytokines in the nasal mucosa of normal and perennial rhinitic subjects. The mast cell as a source of IL-4, IL-5, and IL-6 in human allergic mucosal inflammation. J. Immunol., 151, 3853-3865.

9) Shin, T. Y., Kim, S. H., Choi, C. H., Shin, H. Y. and Kim, H. M. (2004) Isodon japonicus decreases immediate-type allergic reaction and tumor necrosis factor-alpha production. Int. Arch. Allergy Immunol., 135, 17-23.

10) Shin, T. Y., Kim, S. H., Suk, K., Ha, J. H., Kim, I., Lee, M. G., Jun, C. D., Kim, S. Y., Lim, J. P., Eun, J. S., Shin, H. Y. and Kim, H. M. (2005) Antiallergic effects of Lycopus lucidus on mast cell-mediated allergy model. Toxicol. Appl. Pharmacol., 209, 255262.

11) Kim, T. H., Thuy, N. T., Shin, J. H., Baek, H. H. and Lee, H. J. (2000) Aroma-active compounds of miniature beefsteakplant (Mosla dianthera Maxim). J. Agric. Food Chem., 48, 2877-2881.

12) Yook, C. S. (1981) Medical Plants of Korea, Jinmyeong Publishing Co., Seoul, pp. 344-345.

13) Perry, L. M. (1980) Officinal Use of Flowering Plants and Ferns, MIT Press, London, p. 190.

14) Kim, S. H., Choi, C. H., Kim, S. Y., Eun, J. S. and Shin, T. Y. (2005) Antiallergic effects of Artemisia iwayomogi on mast cell-mediated allergy model. Exp. Biol. Med., 230, 82-88.

15) Kim, S. H. and Shin, T. Y. (2005) Amomum xanthiodes inhibits mast cell-mediated allergic reactions through the inhibition of histamine release and inflammatory cytokine production. Exp. Biol. Med., 
230, 681-687.

16) Kim, S. H. and Shin, T. Y. (2006) Effect of Dracocephalum argunense on mast cell-mediated hypersensitivity. Int. Arch. Allergy Immunol., 139, 87-95.

17) Kim, S. H. and Sharma, R. P. (2004) Mercuryinduced apoptosis and necrosis in murine macrophages: role of calcium-induced reactive oxygen species and p38 mitogen-activated protein kinase signaling. Toxicol. Appl. Pharmacol., 196, 47-57.

18) Lee, D. H., Kim, S. H., Eun, J. S. and Shin, T. Y. (2006) Mosla dianthera inhibits mast cell-mediated allergic reactions through the inhibition of histamine release and inflammatory cytokine production. Toxicol. Appl. Pharmacol., 216, 479-484.

19) Mousli, M., Bronner, C., Bockaert, J., Rouot, B. and Landry, Y. (1990) Interaction of substance P, compound 48/80 and mastoparan with the alpha-subunit C-terminus of G protein. Immunol. Lett., 25, 355-
357.

20) Tasaka, K., Mio, M. and Okamoto, M. (1986) Intracellular calcium release induced by histamine releasers and its inhibition by some antiallergic drugs. Ann. Allergy, 56, 464-469.

21) Walsh, L. J., Trinchieri, G., Waldorf, H. A., Whitaker, D. and Murphy, G. F. (1991) Human dermal mast cells contain and release tumor necrosis factor alpha, which induces endothelial leukocyte adhesion molecule 1. Proc. Natl. Acad. Sci. U.S.A., 88, 4220-4224.

22) Sillaber, C., Bevec, D., Butterfield, J. H., Heppner, C., Valenta, R., Scheiner, O., Kraft, D., Lechner, K., Bettelheim, P. and Valent, P. (1993) Tumor necrosis factor alpha and interleukin-1 beta mRNA expression in HMC-1 cells: differential regulation of gene product expression by recombinant interleukin-4. Exp. Hematol., 21, 1271-1275. 